\title{
ArcheoSciences
}

Revue d'archéométrie

33 (suppl.) | 2009

Mémoire du sol, espace des hommes

\section{GPR survey at the Roman town of Mariana (Corsica)}

\section{Lieven Verdonck and Frank Vermeulen}

\section{(2) OpenEdition}

\section{Journals}

Electronic version

URL: https://journals.openedition.org/archeosciences/1635

DOI: 10.4000/archeosciences. 1635

ISBN: 978-2-7535-1599-4

ISSN: 2104-3728

Publisher

Presses universitaires de Rennes

Printed version

Date of publication: 30 October 2009

Number of pages: $241-243$

ISBN: 978-2-7535-0943-6

ISSN: 1960-1360

Electronic reference

Lieven Verdonck and Frank Vermeulen, "GPR survey at the Roman town of Mariana (Corsica)",

ArcheoSciences [Online], 33 (suppl.) | 2009, Online since 30 October 2011, connection on 01 February

2022. URL: http://journals.openedition.org/archeosciences/1635 ; DOI: https://doi.org/10.4000/

archeosciences. 1635 


\title{
GPR survey at the Roman town of Mariana (Corsica)
}

\author{
Lieven VERDONCK* and Frank VermeUlen*
}

Key words: Ground-penetrating radar, archaeological interpretation, three-dimensional visualisation, Roman archaeology, Corsica (France)

In the last ten years, ground-penetrating radar (GPR) has become one of the most valuable methods for the non-invasive investigation of complex urban sites (see e.g. Neubauer et al., 2002; Gaffney et al., 2004; Seren et al., 2004; Leckebusch \& Sütterlin, 2007). This contribution summarizes the first results of a GPR survey, carried out in 2008 at the Roman colonia of Mariana, situated in the valley of the Golo, Northwestern Corsica (Fig. 1). Mariana was founded in $100 \mathrm{BC}$ and flourished until the Early Christian period. It covers an area of around 30 hectares and today is characterized by a relative absence of development. Excavations took place in the 1970s and from 2000 until present day (Pergola, forthcoming) in an area south of the Canonica church (Fig. 2A), where Roman houses and shops, an early medieval cathedral (predecessor of the present church) and a medieval bishop's palace were unearthed. When compared with the town limits derived from aerial photography, these excavations are in an eccentric position. The main motive for the geophysical survey was to shed more light on the town centre from the Early Empire, which was to be found in the fields north of the Canonica. Additionally, it was tried to discover the location of several excavation trenches from the 1930s, which had yielded clear building plans (Nucci, 2001).

The area surveyed was approximately $5000 \mathrm{~m}^{2}$. A Sensors \& Software pulse EKKO PRO GPR was used, with a $500 \mathrm{MHz}$ antenna. The in-line sampling interval was $0.05 \mathrm{~m}$, the line spacing was $0.25 \mathrm{~m}$. Relatively standard processing was applied. Strong reflections caused by metal objects in the topsoil had to be removed. Migration tests with a range of velocities resulted in a high velocity $(0.11 \mathrm{~m} /$ ns) for the very dry topsoil in the month of September, decreasing to around $0.075 \mathrm{~m} / \mathrm{ns}$ at a depth of $1.5 \mathrm{~m}$.

Since the complex results could not easily be interpreted on the basis of profiles or depth-slices alone, a threedimensional interpretation was made (Fig. 3). Methods of automatic or semi-automatic extraction of the relevant archaeological structures have been proposed (Leckebusch, 2008). For the Mariana project, the interpretation was carried out manually, on the basis of $5 \mathrm{~cm}$ thick depth-slices. Since this process is time-consuming, for each feature one slice was selected for defining the horizontal extent: the slice where the feature had the largest extent and where the contrast with the surrounding soil was the sharpest. Furthermore, two slices were selected, representing the top and bottom of the feature. Using the depth of these slices, the feature was then given its vertical extent. As most features in the dataset were walls, this simple box model with six faces can be assumed to represent the real situation relatively adequately, even if it is a simplification. Particular attention was given to possible discontinuities, such as a doorway in a wall or depth variations within a single feature.

The orthogonal layout of the town is immediately noticeable, with two streets dividing the prospected area in four insulae, as well as the correspondence in orientation with the excavated parts south of the Canonica (Fig. 2A). Most of the structures can be recognized as houses (especially in the eastern part of the survey area, e.g. B-D), whereas a big part of the northwestern insula is occupied by what appears to be a large bath complex (E). Additional information could be extracted from a fluxgate magnetometer survey conducted in

\footnotetext{
* Department of Archaeology, Ghent University, Blandijnberg 2, 9000 Ghent, Belgium (Lieven.Verdonck@UGent.be)
} 

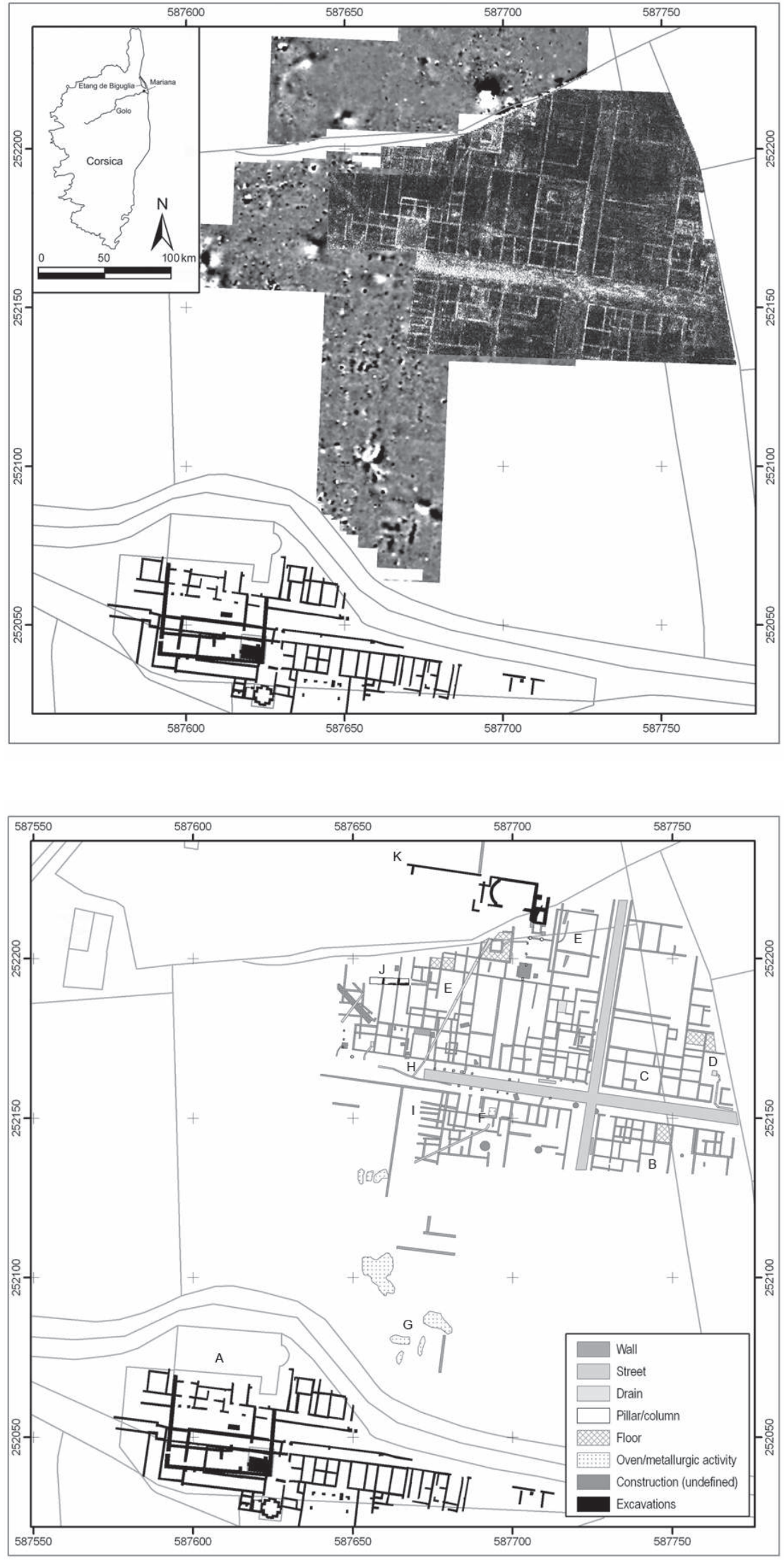

Figure 1: Results of the 2008 GPR survey (depth-slice 0.80-0.85 m), overlying the results of the 2006 fluxgate gradiometer survey. The results from the excavations around the Canonica are indicated in black.

Figure 2: Interpretation of the GPR and gradiometer results, combined with data from the different excavations. A: excavations around Canonica, B-D: houses, E: baths, F-G: ovens/metallurgic activity, $\mathrm{H}$ : drain, I: different building phases of a house, J: test excavation, K: old excavations, georeferenced by means of the geophysical data. 
2006 with a Geoscan Research FM256. For example, strong magnetic anomalies in building

F (southwestern insula) suggest a hypocaust or, more probably, an oven or metallurgic activity. Other magnetic anomalies indicating industrial activity were found more to the south $(G)$. From the GPR survey, parts of the water supply and drainage system of the town could also be detected, e.g. within the baths $(\mathrm{H})$.

In many parts of the town, there are indications of at least two occupation phases. Often, the distance between walls is very small so that they cannot be contemporary (see e.g. Fig. 2I). Some open spaces had a well-defined function in the oldest phase, like the courtyards in the bath complex, but became built up in later phase(s). Moreover, there seems to be a difference in the construction quality of the walls. The walls with the deepest foundations are very straight, are always built exactly according to the main orientation of the town layout and provoke strong GPR-reflections. On the contrary, the shallower ones often slightly deviate from this orientation and their construction seems to be less sturdy. To further investigate this difference, the GPR data were compared with the results from a test trench (Fig. 2J). There, it was observed that the walls causing the strong GPR signals are made of opus testaceum, consisting of large river cobbles in cement with brick facings, and are approximately $0.5 \mathrm{~m}$ wide. The shallower walls, which near the trench were hardly distinguishable in the GPR depth-slices from the background noise, turned out to be alignments of loose cobbles, mostly only one layer thick. The opus testaceum walls and the finds from the excavation point towards a construction date near the end of the first century $\mathrm{AD}$, whereas the overlying layer containing the cobble wall is probably not older than the end of the third century AD.

The combination of GPR and fluxgate gradiometer results, as well as the mapping of a few wall sections still visible above ground allowed locating one of the trenches from the 1930s. The excavation plan (Fig. 2K) shows a large apsidal room and one or two basins, so that it can now be inferred that the baths extend over an area of at least $3000 \mathrm{~m}^{2}$. In this way, old and new excavations of the bath complex have helped to interpret the geophysical data, which in turn have answered a number of questions arisen from the excavations. GPR investigations will continue in 2009, with the aim, among others, of localising the forum of the town.

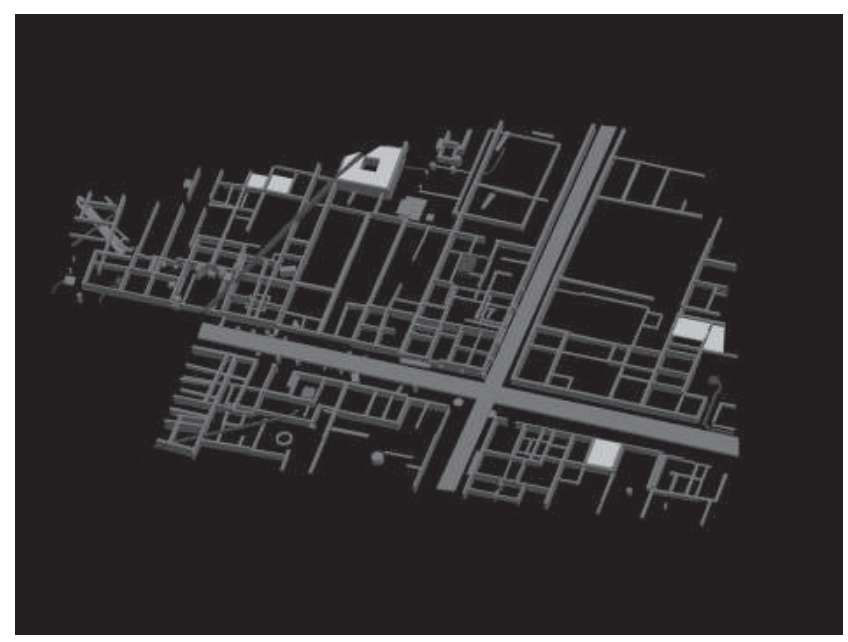

Figure 3: Three-dimensional interpretation of the GPR results. Height has been exaggerated twice.

\section{References}

Gaffney, V., Patterson, H., Piro, S., Goodman, D., Nishimura, Y., 2004. Multimethodological approach to study and characterize Forum Novum (Vescovio, Central Italy). Archaeological Prospection, 11: 201-212.

LeCKebusch, J., Sütterlin, H., 2007. Large scale GPR surveys in Augst. In I. Kuzma (dir.) $7^{\text {th }}$ International Conference on Archaeological Prospection, 210-212.

LeCKebusch, J., 2008. Semi-automatic feature extraction from GPR data for archaeology. Near Surface Geophysics, 6: 75-84.

Neubauer, W., Eder-Hinterleitner, A., Seren, S., Melicher, P., 2002. Georadar in the Roman Civil Town Carnuntum, Austria: an approach for archaeological interpretation of GPR data. Archaeological Prospection, 9: 135-156.

NucCI, F., 2001. Les campagnes de fouilles à Mariana (Corse) en 1936 et 1937 par Louis Leschi et Albert Chauvel. Cahiers Corsica, 195.

Pergola, P. (ed.). forthcoming, Actes du colloque international "Mariana et la basse vallée du Golo", Bastia-Lucciana, France, 10-16 septembre 2004.

Seren, S., Eder-Hinterleitner, A., Neubauer, W., Groh, S., 2004. Combined high-resolution magnetics and GPR surveys of the Roman town of Flavia Solva. Near Surface Geophysics, 2: 63-68. 